\title{
The Utilization of Pyridine by Micro-organisms
}

\author{
BY F. W. MOORE \\ Department of Bacteriology, University of Birmingham
}

SUMMARY : Soil-enrichment cultures in a medium containing $0 \cdot 1 \%(\mathrm{v} / \mathrm{v})$ pyridine as the sole organic compound gave plate counts of more than 1000 million organisms $/ \mathrm{ml}$. Organisms of the genus Proactinomyces were able to utilize pyridine, aniline, nicotinic acid, nitrobenzene, or phenol + ammonium ion as sole source of carbon, nitrogen and energy.

Very little is known of the decomposition by micro-organisms of simple cyclic compounds. The fact that such compounds do not accumulate in the soil indicates that degradation must occur. The chemical stability of such elementary six-membered ring compounds as benzene and pyridine is well known, and it is unlikely that any decomposition takes place in the soil as a result of purely chemical action. The occurrence of the pyridine ring in the form of nicotinic acid or its derivatives appears to be universal in living cells. Co-enzymes I and II each contain the nicotinamide moiety as an essential part of their molecules. The quantities of pyridine ring compounds which are returned to the soil on the death of animal and vegetable cells are extremely difficult to estimate, but it can be assumed that there is a steady supply of such compounds available for decomposition.

References to the dissimilation of pyridine by micro-organisms are few. Buddin (1914), when attempting to sterilize soil by the use of a pyridine solution, found that the pyridine was rapidly broken down by micro-organisms. Funchess (1917) showed that nitrification, using pyridine, occurred in soil; pyridine was almost as good a source of nitrogen for corn and oats as sodium nitrate. Robbins (1917) demonstrated that the bacterial content of soil rose rapidly after the addition of $0 \cdot 1 \%$ pyridine. He isolated a species of bacterium which was capable of growing in a medium containing pyridine as the sole source of nitrogen. den Dooren de Jong (1926) found that pyridine could be used as the sole source of nitrogen by Aerobacter aerogenes, Serratia marcescens and Bacterium herbicola. Ostroff \& Henry (1939) reported the utilization of pyridine as a source of nitrogen by three species of marine bacteria. Koser \& Baird (1944) studied the growth of bacteria on a medium which included nicotinic acid or closely related compounds. They found organisms of the $P$ seudomonas fluorescens group capable of using nicotinic acid as their sole source of carbon, nitrogen and energy. Serratia marcescens and related species were able to grow on a similar medium having $\left(\mathrm{NH}_{4}\right)_{2} \mathrm{HPO}_{4}$ as the nitrogen source. None of these organisms was able to grow when pyridine replaced the nicotinic acid.

\section{Experimental methods}

Medium. The basal culture medium used for most of the work was a modification of that used by Gray \& Thornton (1928): $\mathrm{K}_{2} \mathrm{HPO}_{4}, \mathbf{1 . 0} \mathrm{g} \cdot ; \mathrm{MgSO}_{4} \cdot 7 \mathrm{H}_{2} \mathrm{O}$, 0.2 g.; NaCl, $0 \cdot 1$ g.; $\mathrm{CaCl}_{2}, 0 \cdot 1$ g.; $\left(\mathrm{NH}_{4}\right)_{2} \mathrm{SO}_{4}$ or $\mathrm{KNO}_{3}, 1 \cdot 0$ g.; pyridine A.R., 
$1.0 \mathrm{ml}$.; dist. water to $1000 \mathrm{ml}$. The $\mathrm{pH}$ was adjusted to $\mathbf{7 \cdot 2 - 7 \cdot 4}$, and the medium sterilized by autoclaving for $20 \mathrm{~min}$. at $15 \mathrm{lb} . / \mathrm{sq}$.in. pressure. Solid medium was prepared by adding $400 \mathrm{ml}$. of $5 \%$ agar (well-washed) to $600 \mathrm{ml}$. of the basal medium. Occasionally the composition of the medium was modified by the omission of the inorganic source of nitrogen, or by varying the percentage of pyridine.

\section{Preliminary enrichment}

Five g. of garden soil were shaken with $50 \mathrm{ml}$. of quarter-strength Ringer's solution. After standing for $5 \mathrm{~min} ., 1 \mathrm{ml}$. of this suspension was added to $100 \mathrm{ml}$. of the basal medium, which included ammonium sulphate, and another $1 \mathrm{ml}$. was added to $100 \mathrm{ml}$. of the basal medium containing potassium nitrate. These liquid cultures were incubated at room temperature $\left(15-20^{\circ}\right)$ for 7 days.

Examination of stained and unstained preparations showed large numbers of non-motile, much-branched filamentous organisms, and smaller numbers of motile rods, non-motile cocci and Protozoa. These mixed cultures were subcultured by transferring one loopful of the liquid to $20 \mathrm{ml}$. of basal medium containing either $\left(\mathrm{NH}_{4}\right)_{2} \mathrm{SO}_{4}$ or $\mathrm{KNO}_{3}$. This subcultivation and enrichment was carried out four times, the cultures being incubated at room temperature for 5 days.

\section{Isolation}

Decimal dilutions to $1 / 10,000,000$ of the final enrichment cultures were prepared in sterile quarter-strength Ringer's solution. Two drops $(c .0 \cdot 1 \mathrm{ml}$.) of each dilution were spread over the surface of previously poured and surface dried plates of Lemco nutrient agar, which were incubated at room temperature for 10 days. Plates prepared from the highest dilutions $(\mathbf{1} / \mathbf{1 0 , 0 0 0 , 0 0 0 )}$ averaged 15-20 colonies/plate, indicating that the final enrichment cultures contained at least 1500 million organisms $/ \mathrm{ml}$. Isolated colonies were subcultured on Lemco agar slopes, and the resulting growths were again subcultured into the basal pyridine medium which included the same inorganic source of nitrogen as the enrichment culture from which the organism was isolated. Two more subcultures into the pyridine medium were carried out at 5-day intervals to minimize the carry-over of organic matter from the Lemco agar. Tubes showing visible growth were then subcultured into the basal medium without the inorganic nitrogen.

\section{Identification}

The organisms forming colonies on Lemco agar plates were classified by microscopical and cultural examination, as follows: Proactinomyces, c. $40 \%$; Gram-negative rods (mainly Pseudomonas sp.), c. 30\%; Actinomyces, c. 15\%; Gram-positive cocci and rods, c. $15 \%$.

When these organisms were inoculated in pure culture into the pyridine medium, almost every organism showed some growth in the first subculture. This was probably due to the fact that the initial inoculum was heavy and that a small quantity of organic matter was carried over. It was found that all the 
Proactinomyces organisms were capable of continued growth in the basal pyridine medium, whereas none of the other organisms would grow in pure culture in it, even when an inorganic nitrogen compound was also present. The large number of organisms of the Pseudomonas type found in the final enrichment cultures suggests that, once the pyridine ring is broken by the Proactinomyces species, the pseudomonads are able to utilize the decomposition products as sources of carbon, nitrogen and energy.

There were two distinct groups of Proactinomyces present. The first group, which included about ten morphologically distinct types, was characterized by the production of a small, rather unstable, branched mycelium, which appeared

\section{Table 1. Effect of pyridine concentration on the growth of Proactinomyces}

The results were classified by visual examination into four degrees of turbidity: - no visible growth; + slight growth; ++ medium growth; +++ heavy growth.

Duration of incubation (days)

\begin{tabular}{|c|c|c|c|c|c|c|c|}
\hline \multirow{2}{*}{$\begin{array}{c}\text { Concentration } \\
\text { of pyridine } \\
\%(v / v)\end{array}$} & 2 & \multicolumn{5}{|c|}{ Relative turbidity } & 43 \\
\hline & & & & & & & \\
\hline $\begin{array}{l}0.05 \\
0 \cdot 10\end{array}$ & $\begin{array}{l}+ \\
+\end{array}$ & $\begin{array}{l}+ \\
++\end{array}$ & $\begin{array}{c}++ \\
+++\end{array}$ & $\begin{array}{c}++ \\
++t\end{array}$ & $\begin{array}{c}++ \\
+++\end{array}$ & $\begin{array}{c}++ \\
+++\end{array}$ & $\begin{array}{c}++ \\
++t\end{array}$ \\
\hline $0 \cdot 15$ & + & ++ & $+t+$ & $+t+$ & +++ & $++t$ & +++ \\
\hline $0 \cdot 20$ & - & + & ++ & $++t$ & $++t$ & +++ & +++ \\
\hline $0 \cdot 25$ & - & + & + & ++ & $+t+$ & +++ & +++ \\
\hline $0 \cdot 30$ & - & - & + & ++ & $+t+$ & +++ & +++ \\
\hline 0.35 & - & - & - & + & ++ & +++ & +++ \\
\hline 0.40 & - & - & - & - & + & ++ & $+t+$ \\
\hline 0.45 & - & - & - & - & + & + & ++ \\
\hline 0.50 & - & - & - & - & - & + & + \\
\hline
\end{tabular}

granular when stained by Gram's method. Surface colonies on Lemco agar were pinkish, glistening and easily emulsified. A heavy sediment was produced in liquid culture. The second group, the various strains of which closely resembled one another, produced a relatively stable, much-branched and matted mycelium. Surface colonies were white, dull, waxy and difficult to emulsify. In liquid culture, a pellicle of the 'powdered chalk' type was produced, together with a flocculent growth which occasionally adhered to, and formed colonies on, the inner surface of the tube.

\section{Growth in various concentrations of pyridine}

The basal medium was modified by omitting the inorganic source of nitrogen, and by adding pyridine to give the following percentage $(\mathrm{v} / \mathrm{v})$ concentrations $0 \cdot 05,0 \cdot 10,0 \cdot 15,0 \cdot 20,0 \cdot 25,0 \cdot 30,0.35,0.40,0.45$ and 0.50 . All the strains of organisms utilizing pyridine were subcultured from 4-day cultures in $0 \cdot 10 \%(\mathrm{v} / \mathrm{v})$ pyridine medium into the liquid media of varied pyridine concentration. The results are shown in Table 1. All strains seemed to follow the same pattern, growth being more rapid in the lower concentrations and reaching a maximum after 5 days. As the concentration of pyridine was increased, the initial lag 
period was extended. In the case of $0.50 \%$ pyridine, no growth was visible for 21 days, and a maximum was not reached until 70-90 days.

The remainder of the investigation was carried out on two strains of Proactinomyces, one from each of the two groups mentioned earlier. The basal medium was modified by the substitution of other cyclic compounds in the place of pyridine. The concentrations used were $0 \cdot 10 \%(\mathrm{w} / \mathrm{v})$ of phenol and of nicotinic acid, and $0 \cdot 10 \%(\mathrm{v} / \mathrm{v})$ of aniline and of nitrobenzene. Both organisms were able to use the cyclic compound as the sole source of carbon, nitrogen and energy for their growth, except in the case of phenol, which was utilized when $0 \cdot 1 \%$ ammonium sulphate was added.

\section{Some products of metabolism}

Crystals formed in liquid cultures of each type of organism; these crystals gave positive reactions for calcium and oxalate. As the carbon:nitrogen ratio of pyridine is approximately $4: 1$, it is unlikely that the organisms assimilate all the nitrogen present in the medium. Microchemical tests for nitrate, nitrite and hydroxylamine gave uniformly negative results at all stages of growth. The progressive production of ammonia was demonstrated by the use of Nessler's reagent.

\section{DISCUSSION}

Previous evidence of the growth of pure cultures of micro-organisms in media containing unsubstituted six-membered ring compounds as their sole source of carbon and energy has been provided by Tausson (1929), who demonstrated that benzene was utilized by an organism which he called Bact. benzoli. Grant \& ZoBell (1944), using absorption of oxygen as evidence of growth, reported that certain marine bacteria could utilize benzene.

The stability of unsubstituted aromatic compounds to microbial attack has been noted by many workers. ZoBell (1948) states that 'aromatic and naphthenic hydrocarbons having side-chains appear to be attacked more readily than similar homologues without side-chains'. Stanier (1948) found that benzene, toluene and xylene were not decomposed by fluorescent pseudomonads. The bacteria studied by Tausz \& Peter (1919) failed to attack benzene.

On the other hand, reports of the breakdown of substituted cyclic compounds such as phenol, benzoic acid and nicotinic acid are more numerous (see Gray \& Thornton, 1928; Stanier, 1948; and Koser \& Baird, 1944). It appears that the substitution of one of the hydrogen atoms of the benzene or pyridine nucleus by a reactive group, such as $-\mathrm{OH}$ or $-\mathrm{COOH}$, leads to a certain degree of susceptibility to microbial attack.

Pseudomonads and other Gram-negative rods have been shown to be capable of utilizing cyclic compounds as their sole source of carbon and energy by den Dooren de Jong (1926), Gray \& Thornton (1928), Koser \& Baird (1944) and Stanier (1948). It is interesting to note that although large numbers of motile Gram-negative rods were present in pyridine enrichment cultures, these organisms would not grow in pure culture in the pyridine media. Apparently Proactinomyces breaks down the pyridine molecule in such a way that the 
products can satisfy the carbon, nitrogen and energy requirements of the Gram-negative rods as well as its own needs. Other organisms, reported by den Dooren de Jong (1926), Robbins (1917) and Ostroff \& Henry (1939) to be capable of utilizing pyridine as a source of nitrogen and thus of rupturing the ring, could not satisfy their carbon and energy requirements with the remainder of the molecule, but needed an additional carbon compound, such as glucose. It appears from the evidence presented that, in pure culture, the utilization of pyridine as a sole source of carbon, nitrogen and energy is limited to organisms of the genus Proactinomyces, although certain other bacteria are able to grow in mixed culture with Proactinomyces, or to utilize pyridine as a source of nitrogen.

\section{REFERENCES}

Buddin, W. (1914). Partial sterilization of soil by volatile and non-volatile antiseptics. J. agric. Sci. 6, 417-55.

Dooren DE Jong, L. E. DEN (1926). Bijdrage tot de kennis van het mineralisatieproces. Thesis. Delft. Quoted by Stephenson, M. (1939). Bacterial Metabolism, 2nd ed. London: Longmans, Green and Co.

Funchess, M. J. (1917). The nitrification of pyridine, quinoline, etc., in soils. Bull. Ala. agric. Exp. Sta. no. 196 (Tech. Bull. no. 3.).

Grant, C. W. \& ZoBell, C. E. (1944). Oxidation of hydrocarbons by marine bacteria. Proc. Soc. exp. Biol., N.Y., 51, 266-7.

Gray, P. H. H. \& Thornton, H. G. (1928). Soil bacteria that decompose certain aromatic compounds. Z Zbl. Bakt. (2. Abt.), 73, 74-96.

Koser, S. A. \& BaInd, G. R. (1944). Bacterial destruction of nicotinic acid. J. infect. Dis. 75, 250-61.

OStroff, R. \& HeNry, B. S. (1939). The utilization of various nitrogen compounds by marine bacteria. J. cell. comp. Physiol. 13, 353-71.

Robsins, W. J. (1917). The cause of the disappearance of cumarin, vanillin, pyridine and quinoline in the soil. Bull. Ala. agric. Exp. Sta. no. 195 (Tech. Bull. no. 3).

Stanier, R. Y. (1948). The oxidation of aromatic compounds by fluorescent pseudomonads. J. Bact. 55, 477-94.

Tausson, W. O. (1929). Ueber die Oxydation der Benzolkohlenstoffe durch Bakterien. Planta, 7, 735-58. (Quoted in Chem. Abstr. (1929), 23, 3945.)

Tausz, J. \& Peter, M. (1919). Neue Methode der Kohlenwasserstoffanalyse mit Hilfe von Bakterien. Z Zbl. Bakt. (2. Abt.), 49, 497-554.

ZoBeLI, C. E. (1948). Microbial transformation of hydrocarbons. J. gen. Microbiol. 2, Proc. viii. 